\title{
Curved characteristics best suited for Growth rates, Relative strength and Performance Time of female Olympic weightlifters
}

\author{
Khaled EBADA
}

Department of Theories and Applications Compats and Individual Sports, Faculty of Physical Education in Port Said University, Egypt. Address correspondence to Khaled Ebada, kebada@phyd.psu.edu.eg

\begin{abstract}
This study aims to identify Growth rates, Relative strength, and performance time for female lifters and defining Curved characteristics best suited for growth rates, relative strength, and performance Time of female Olympic weightlifters and evaluate the performance of snatch and Clean \& Jerk for female lifters, coaches use the curved characteristics as standard guide them through planning and preparing training programs. The study Applied on a sample of 88 female lifter participants in weightlifting competitions at the 2012 Summer Olympics in London, Where the average age of 25.61 \pm 3.68 years, length 160.18 $\pm 6.27 \mathrm{~cm}$, weight $67.04 \pm 14.33 \mathrm{~kg}$ and BMI $25.78 \pm 3.99 \mathrm{~kg} . / \mathrm{m}^{2}$. Were analyzed video film, which was filmed for female lifters knowledge of the technical Committee of the International weightlifting Federation during the Olympic Games in London 2012. The movie was filmed with a video camera at 25 frames/second that is an attempt to analyze the best female lifters to determine for the performance time phases Snatch and Clean \& Jerk and using the program Kinovea Version 0.8 .15 of kinetic analysis. It was found the rate of BMI and the relative strength of female lifters. The results showed final curved characteristics best suited for growth rates, relative strength, results lifts and performance time phases of female Olympic weightlifters, and determine the standard to assess the performance of Snatch and Clean \& Jerk in weightlifting. These results must be taken into account by the coaches and female lifters to use the standard guide them through planning, preparing weightlifting training programs and to evaluate the performance of snatch and Clean \& Jerk lifts for female lifters. Modified the weight categories for female weightlifters beginning of $63 \mathrm{~kg}$ weight for the following class of $2-3 \mathrm{~kg}$ until the distinction between the different weight categories results in female lifters, which can achieve for new Olympic Records in female weightlifting competitions.
\end{abstract}

Keywords: Female lifters, weightlifting, Olympic, snatch, clean and jerk, relative strength.

\section{INTRODUCTION}

Female Olympic weightlifting characterized techniques for the snatch and clean \& jerk by an increased barbell displacement from platform to an overhead position. Which is referred to as the performance phases as follows for Snatch (Pull Phase I - Pull Phase II - Squat- standing up), while you are for Clean \& Jerk (Pull Phase I - Pull Phase II - Squat- standing up clean - Jerk- stand up from jerk) $(2,9,10,20)$. The growth rates and the relative strength and performance time indicators evolution maximal strength and performance for female weightlifting depend where evaluating the relationship between strength and weightlifters performance skills of different length, body mass and performance time $(9,11,27)$.

This study puts the determinants and standards for growth rates, the relative strength and lifts performance time phases to evaluate the results snatch, clean \&jerk lifts and female Weightlifters performance. Where focused most of the studies conducted on female weightlifting study biomechanical characteristics to snatch and clean \& jerk. Studies have specifically focused on barbell path in relation to body position, barbell velocity, mechanical work and power output $(15,16,26,33)$ lacked These studies do not specify the curved characteristics best suited for the growth rates, relative strength and performance phases time for female lifters as a criterion to evaluate the results and performance of female Weightlifting.

By studying the results of cycles Olympic weightlifting competitions in the period from 2000 Sydney to 2012 London $(31,16,17)$, which involved for the female Egyptian weightlifter team. That there is a clear difference in the achievement of digital female Egyptian lifter, when compared to the level of Olympic. May be due the difference is obvious to the non-availability of adequate information on the standards Growth rates, relative strength and Performance time required to female lifter the one 
hand, and the lack of exact standard to determine deficiencies in the performance of the other hand. The researcher noted through its expertise in the field of weightlifting, brief him on studies, scientific research, references specialized weightlifting, within science researcher found that there is a dearth of research studies for determining the Curved characteristics best suited for female weightlifters to evaluate the level of performance skills. Prompting the researcher to conduct this study to identify Growth rates, Relative strength and performance time for female lifters, and defining Curved characteristics best suited for growth rates, relative strength, and performance time of female Olympic weightlifters. To evaluate the performance of snatch and Clean \& Jerk for female lifters and coaches to use the standard guide them through planning and preparing weightlifting training programs.

\section{MATERALS \& METHODS}

The study was carried out on a sample of 88 female lifter participants in weightlifting competitions at the 2012 Summer Olympics in London, Where the average age of $25,61 \pm 3.68$ years, length $160.18 \pm 6.27 \mathrm{~cm}$, weight $67.04 \pm 14.33 \mathrm{~kg}$ and BMI $25.78 \pm 3.99 \mathrm{~kg} . / \mathrm{m}^{2}$. Data regarding the female lifters length, age and results lift the were obtained through the official website of the London Olympics 2012, International weightlifting Federation and BBC sport Olympics $(16,17)$. Were analyzed video film, which was filmed for female lifters knowledge of the Technical Committee of the International weightlifting Federation during the Olympic Games in London 2012. The movie was filmed with a video camera at 25 frames/second. Is an attempt to analyze the best female lifters to determine for the performance time phases Snatch and Clean \& Jerk and using the program Kinovea Version 0.8.15 of kinetic analysis. It was found the rate of body mass index (BMI) and relative strength (RS.) of female lifters where the ladies were calculated BMI by the following formula: BMI=Weight $(\mathrm{kg}) /(\text { Length }(\mathrm{m}))^{2}$, and calculate the relative strength of the following formula: RS.= Maximum strength/Body weight $(8,14,19)$. In the period from 1.2.2014 to 15.2.2014. The researcher analyzed Kinetic skill of study for members of female lifters in weightlifting at the 2012 Olympics in London, where 88 attempts were analyzed by using a program Kinovea Version 0.8.15 for performance time analysis according to following model Figure 1 and 2.

Analyzed are four main phases to snatch a performance (Pull Phase I - Pull Phase II - Squatstanding up) and analyzed are Six main phases to Clean \& Jerk a performance (Pull Phase I - Pull Phase II - Squat- standing up clean - Jerk- stand up from jerk) $(1,4,9,10)$. Calculates of Performance time according to following formulas: Calculates of Performance time according to the following formulas have been specified time (T.) for each phase of performance from the beginning to the end of the phase to Snatch and Clean\& jerk as Figure 3, 4 $(21,24,23,25)$.

Statistical analysis: SPSS statistics 19 was used to apply formulas statistical by calculating: Mean (M.), Standard Deviation (S.D), Percentile Score and formulas Six Sigma score (5). Constant =3(S.D) $/ 50$.

\section{RESULTS}

Table 1 descriptive Statistics of the growth rates, the results of Snatch, Clean \& jerk and total results in the different weight categories for female weightlifting at the 2012 Olympics in London.

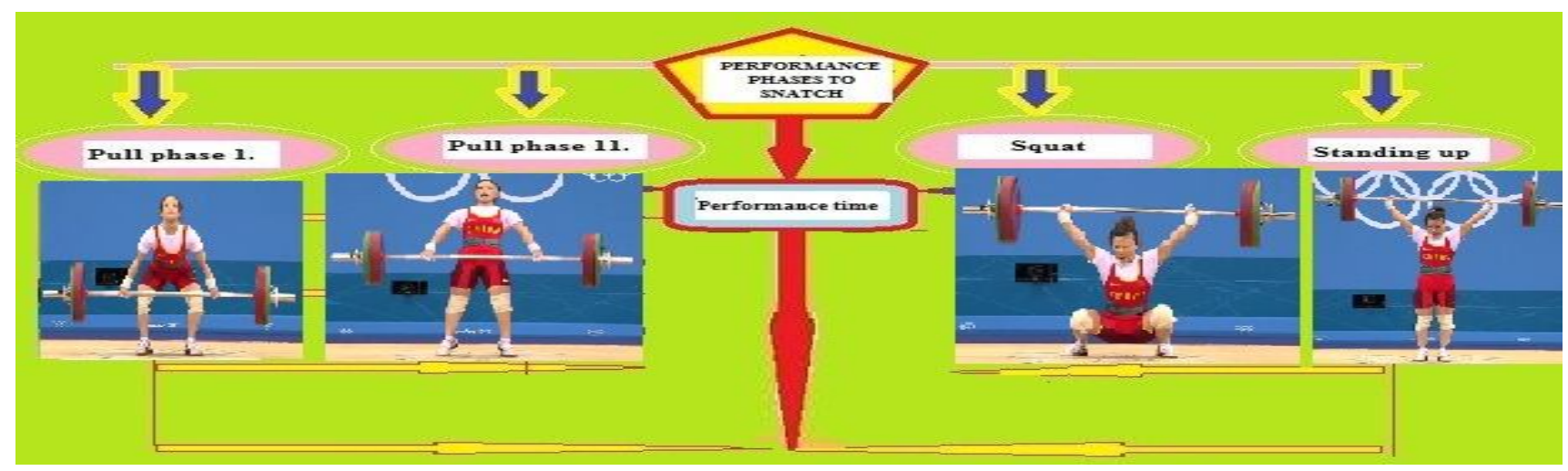

Figure 1. Model Performance time analysis to snatch. 


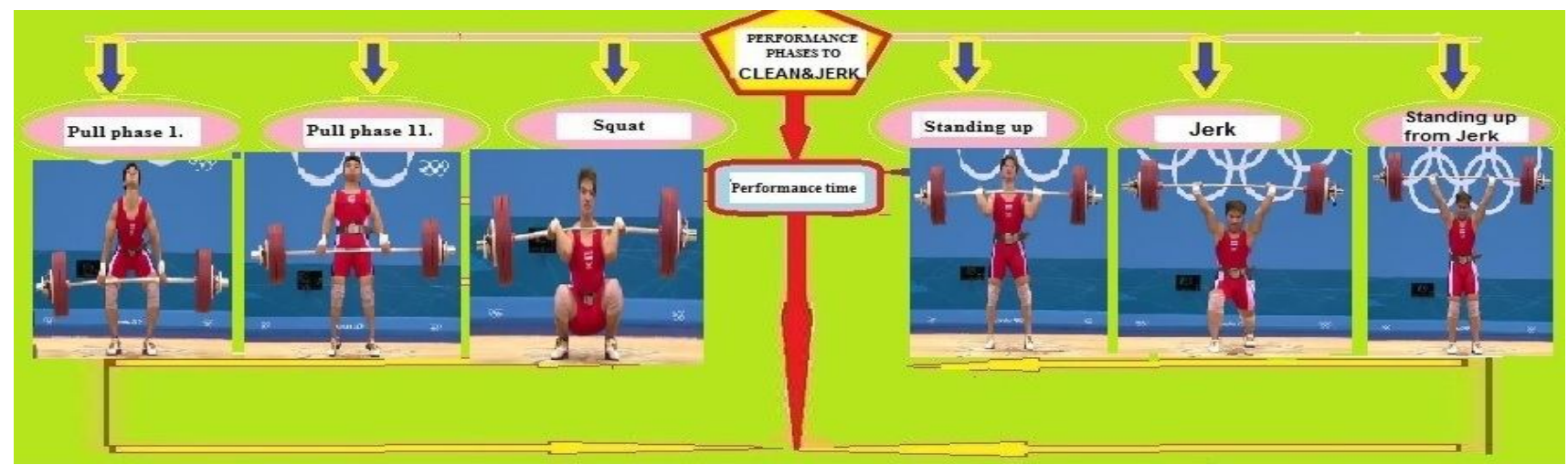

Figure 2. Model Performance time analysis to Clean \& Jerk

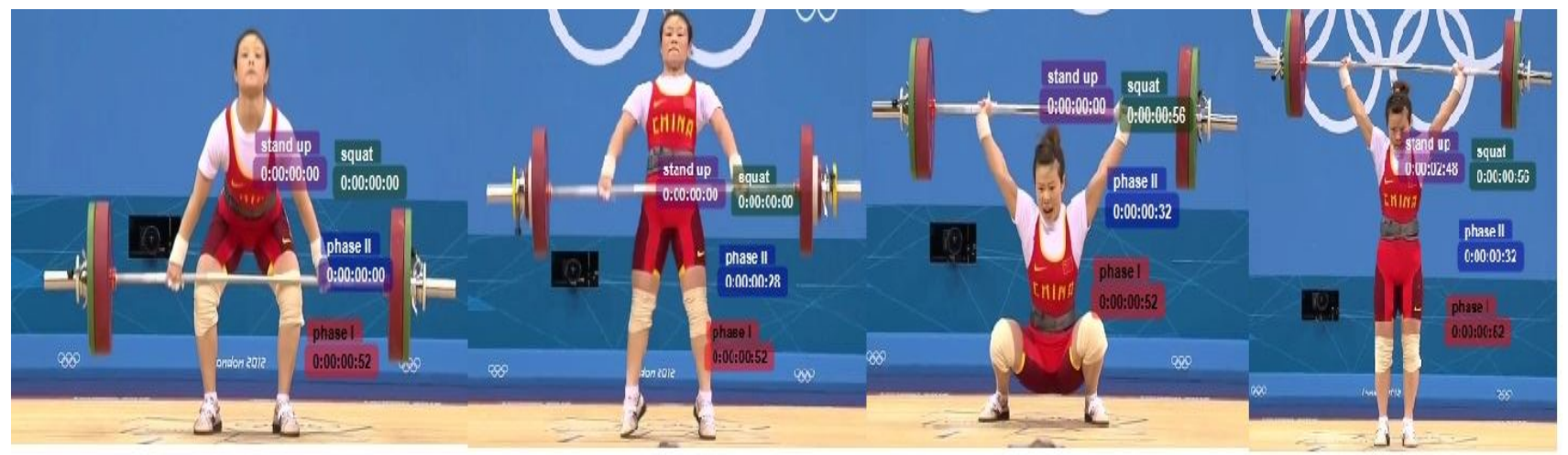

Figure3. Model analysis performance time phase for chinshanlo Zulfiya lifter winning first place in snatch of 53kg weight.

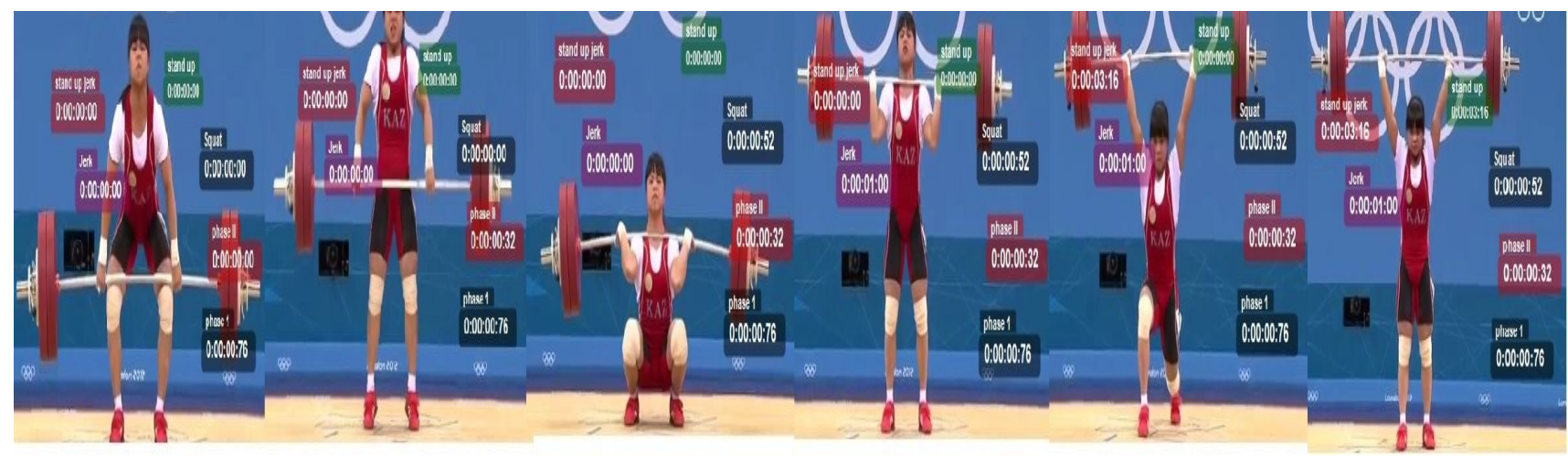

Figure4. Model analysis performance time phase for hsu Shu-Ching lifter winning second place in Clean \& Jerk of 53kg weight.

Table 1. Descriptive Statistics for Growth rates and the results of snatch and Clean \& Jerk for female Olympic weightlifters

\begin{tabular}{|c|c|c|c|c|c|c|c|c|c|c|c|c|c|c|}
\hline \multirow{3}{*}{$\begin{array}{l}\text { Weight } \\
\text { categories }\end{array}$} & \multicolumn{8}{|c|}{ Growth rates } & \multicolumn{6}{|c|}{ Results } \\
\hline & \multicolumn{2}{|c|}{ Age (y) } & \multicolumn{2}{|c|}{ B. weight (kg.) } & \multicolumn{2}{|c|}{ BMI (kg./m²) } & \multicolumn{2}{|c|}{ Length $(\mathrm{cm})$} & \multicolumn{2}{|c|}{ Snatch $(\mathrm{kg})$} & \multicolumn{2}{|c|}{ Cl \& Jerk (kg.) } & \multicolumn{2}{|c|}{ Total (kg.) } \\
\hline & Mean & $\pm \mathrm{SD}$ & Mean & $\pm \mathrm{SD}$ & Mean & $\pm \mathrm{SD}$ & Mean & $\pm \mathrm{SD}$ & Mean & $\pm \mathrm{SD}$ & Mean & $\pm \mathrm{SD}$ & Mean & $\pm \mathrm{SD}$ \\
\hline $48 \mathrm{~kg}$ & 23.91 & 4.28 & 47.59 & 0.21 & 21.29 & 0.97 & 149.73 & 3.52 & 77.45 & 6.96 & 100.27 & 8.66 & 177.73 & 15.16 \\
\hline $53 \mathrm{~kg}$ & 25.67 & 3.33 & 52.55 & 0.16 & 21.59 & 1.32 & 156.73 & 5.38 & 86.00 & 6.27 & 109.20 & 7.95 & 195.20 & 12.61 \\
\hline $58 \mathrm{~kg}$ & 24.69 & 3.31 & 57.65 & 0.27 & 23.45 & 1.20 & 157.00 & 4.13 & 98.00 & 6.00 & 123.38 & 8.20 & 221.38 & 13.78 \\
\hline $63 \mathrm{~kg}$ & 27.44 & 2.96 & 61.62 & 1.25 & 23.50 & 0.74 & 162.00 & 3.33 & 96.78 & 11.19 & 119.89 & 13.26 & 216.67 & 24.44 \\
\hline $69 \mathrm{~kg}$ & 27.15 & 5.42 & 68.43 & 0.29 & 26.23 & 0.85 & 161.62 & 2.66 & 105.08 & 8.69 & 130.23 & 10.49 & 235.31 & 19.01 \\
\hline $75 \mathrm{~kg}$ & 24.92 & 3.11 & 74.18 & 0.75 & 27.44 & 0.95 & 164.58 & 3.01 & 105.92 & 16.58 & 130.83 & 16.67 & 236.75 & 33.25 \\
\hline$+75 \mathrm{~kg}$ & 26.00 & 3.00 & 110.92 & 16.77 & 37.83 & 4.66 & 171.00 & 4.83 & 118.00 & 14.00 & 148.25 & 18.92 & 266.25 & 32.42 \\
\hline
\end{tabular}

Table 2 descriptive Statistics of the RS Snatch, phase's time and performance total T. of snatch lift in the different weight categories for female weightlifting at the 2012 Olympics in London.

Turk ل Sport Exe 2014; IG(I): III6-127

匹 2014 Department of Physical Education and Sport, Selcuk University
Table 3 descriptive Statistics of the RS. Snatch, time phase and performance total T. of Clean \& Jerk lift in the different weight categories for female weightlifting at the 2012 Olympics in London. 
Figure 5 shows the curved characteristics best suited for standard levels of the Growth rates, results of Snatch, Clean \& jerk and results total in the different weight categories for female weightlifters.
Figure 6 shows the curved characteristics best suited for standard levels of the RS. Snatch, Performance time phase and performance total $\mathrm{T}$. for snatch lift in the different weight categories for female weightlifters.

Table 2. Descriptive Statistics for Relative strength and performance Time phases of snatch for female Olympic weightlifters

\begin{tabular}{|c|c|c|c|c|c|c|c|c|c|c|c|c|}
\hline \multirow{3}{*}{ Weight categories } & \multicolumn{10}{|c|}{ Performance Time phase for Snatch lift (Sec.) } & \multirow{2}{*}{\multicolumn{2}{|c|}{$\begin{array}{c}\text { RS. } \\
\text { Snatch }\end{array}$}} \\
\hline & \multicolumn{2}{|c|}{ Pull phase I. } & \multicolumn{2}{|c|}{ Pull phase II. } & \multicolumn{2}{|c|}{ Squat } & \multicolumn{2}{|c|}{ Standing up } & \multicolumn{2}{|c|}{ Total T. } & & \\
\hline & Mean & $\pm S D$ & Mean & $\pm S D$ & Mean & $\pm S D$ & Mean & $\pm S D$ & Mean & $\pm S D$ & Mean & $\pm \mathrm{SD}$ \\
\hline $48 \mathrm{~kg}$ & 0.45 & 0.07 & 0.27 & 0.02 & 0.53 & 0.04 & 2.51 & 0.03 & 3.76 & 0.09 & 1.63 & 0.15 \\
\hline $53 \mathrm{~kg}$ & 0.58 & 0.07 & 0.31 & 0.02 & 0.61 & 0.06 & 2.55 & 0.09 & 4.05 & 0.19 & 1.64 & 0.12 \\
\hline $58 \mathrm{~kg}$ & 0.57 & 0.01 & 0.33 & 0.01 & 0.65 & 0.04 & 2.46 & 0.01 & 4.01 & 0.06 & 1.70 & 0.11 \\
\hline $63 \mathrm{~kg}$ & 0.54 & 0.02 & 0.30 & 0.02 & 0.68 & 0.01 & 3.21 & 0.54 & 4.73 & 0.53 & 1.57 & 0.15 \\
\hline $69 \mathrm{~kg}$ & 0.71 & 0.04 & 0.31 & 0.02 & 0.83 & 0.08 & 3.45 & 0.32 & 5.29 & 0.39 & 1.54 & 0.13 \\
\hline $75 \mathrm{~kg}$ & 0.64 & 0.05 & 0.31 & 0.02 & 0.48 & 0.03 & 2.95 & 0.28 & 4.37 & 0.28 & 1.43 & 0.22 \\
\hline$+75 \mathrm{~kg}$ & 0.57 & 0.03 & 0.29 & 0.02 & 0.56 & 0.02 & 3.76 & 0.33 & 5.18 & 0.32 & 1.09 & 0.16 \\
\hline
\end{tabular}

Table 3. Descriptive Statistics for Relative strength and performance Time phases of Clean \& Jerk for female Olympic weightlifters

\begin{tabular}{|c|c|c|c|c|c|c|c|c|c|c|c|c|c|c|c|c|}
\hline \multirow{3}{*}{$\begin{array}{l}\text { Weight } \\
\text { categories }\end{array}$} & \multicolumn{14}{|c|}{ Performance Time phase for Clean \& Jerk lift (Sec.) } & \multirow{2}{*}{\multicolumn{2}{|c|}{$\begin{array}{c}\text { RS. } \\
\text { Clean\& Jerk }\end{array}$}} \\
\hline & \multicolumn{2}{|c|}{ Pull phase I. } & \multicolumn{2}{|c|}{$\begin{array}{c}\text { Pull phase } \\
\text { II. }\end{array}$} & \multicolumn{2}{|c|}{ Squat } & \multicolumn{2}{|c|}{$\begin{array}{c}\text { Standing up } \\
\text { clean }\end{array}$} & \multicolumn{2}{|c|}{ Jerk } & \multicolumn{2}{|c|}{$\begin{array}{l}\text { Standing up } \\
\text { from Jerk }\end{array}$} & \multicolumn{2}{|c|}{ Total T. } & & \\
\hline & Mean & $\pm \mathrm{SD}$ & Mean & $\pm \mathrm{SD}$ & Mean & $\pm \mathrm{SD}$ & Mean & $\pm \mathrm{SD}$ & Mean & $\pm \mathrm{SD}$ & Mean & $\pm \mathrm{SD}$ & Mean & $\pm \mathrm{SD}$ & Mean & $\pm \mathrm{SD}$ \\
\hline $48 \mathrm{~kg}$ & 0.51 & 0.05 & 0.31 & 0.04 & 0.51 & 0.03 & 3.52 & 0.36 & 2.20 & 0.33 & 2.26 & 0.08 & 9.36 & 0.39 & 2.11 & 0.19 \\
\hline $53 \mathrm{~kg}$ & 0.48 & 0.08 & 0.32 & 0.03 & 0.51 & 0.05 & 1.79 & 0.22 & 3.32 & 0.16 & 2.43 & 0.29 & 8.85 & 0.28 & 2.08 & 0.15 \\
\hline $58 \mathrm{~kg}$ & 0.61 & 0.06 & 0.34 & 0.03 & 0.60 & 0.02 & 1.73 & 0.11 & 2.47 & 0.28 & 2.21 & 0.09 & 7.96 & 0.36 & 2.14 & 0.14 \\
\hline $63 \mathrm{~kg}$ & 0.71 & 0.07 & 0.33 & 0.01 & 0.52 & 0.06 & 2.33 & 0.26 & 3.01 & 0.39 & 3.17 & 0.07 & 10.07 & 0.60 & 1.94 & 0.18 \\
\hline $69 \mathrm{~kg}$ & 0.77 & 0.12 & 0.42 & 0.03 & 0.60 & 0.08 & 2.54 & 0.14 & 3.83 & 0.51 & 4.28 & 0.44 & 12.44 & 1.03 & 1.90 & 0.15 \\
\hline $75 \mathrm{~kg}$ & 0.64 & 0.08 & 0.26 & 0.03 & 0.66 & 0.03 & 1.59 & 0.16 & 3.28 & 0.08 & 2.66 & 0.23 & 9.08 & 0.29 & 1.76 & 0.22 \\
\hline$+75 \mathrm{~kg}$ & 0.79 & 0.11 & 0.35 & 0.02 & 0.61 & 0.05 & 2.13 & 0.29 & 4.26 & 0.64 & 2.24 & 0.10 & 10.39 & 0.79 & 1.36 & 0.20 \\
\hline
\end{tabular}

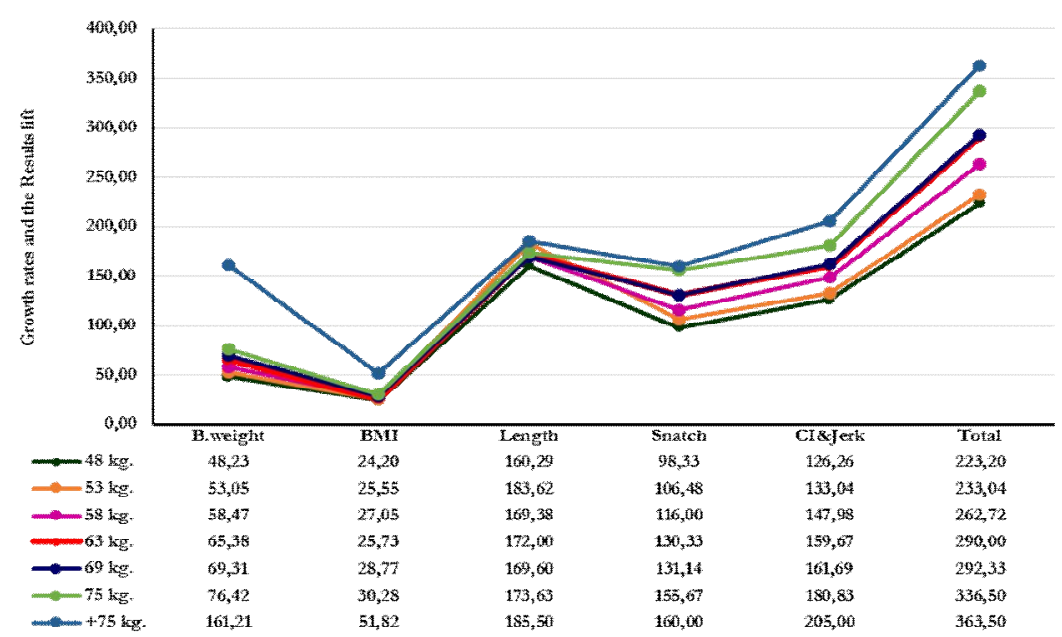

Figure 5. Curved characteristics best suited for growth rates and performance level in weight categories for female Olympic weightlifters. 


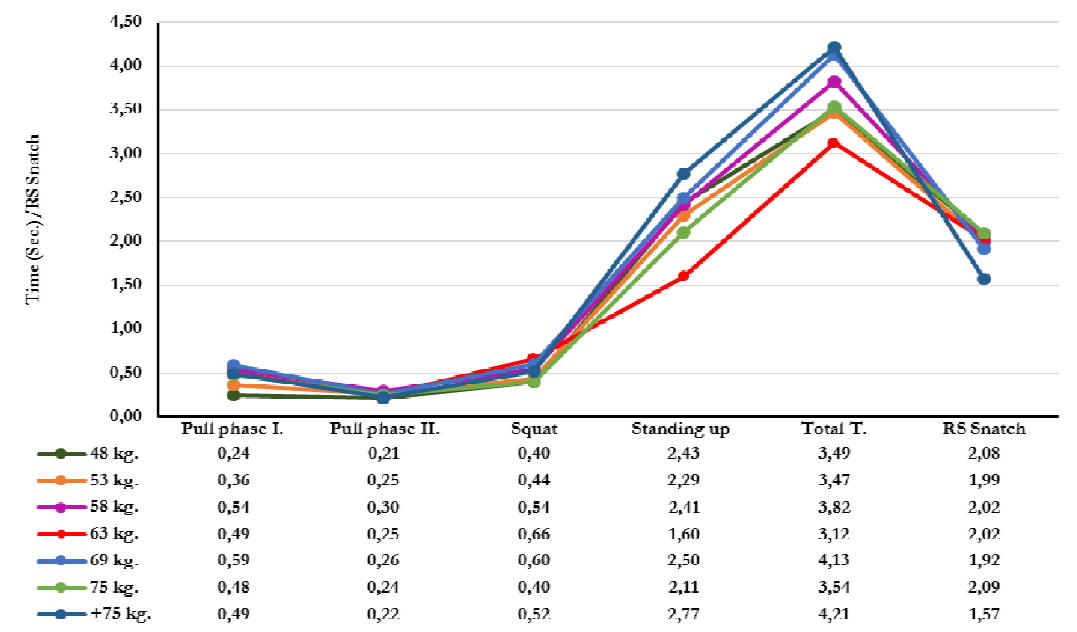

Figure 6. Curved characteristics best suited for Relative strength and performance time of Snatch in weight categories for female Olympic weightlifters.

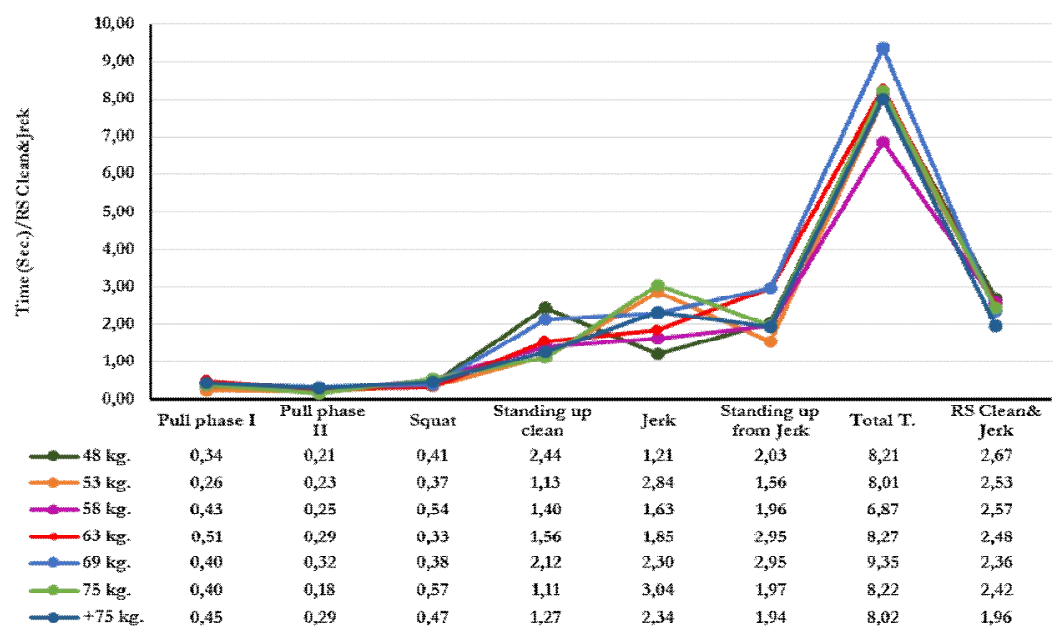

Figure 7. Curved characteristics best suited for Relative strength and performance time of Clean \& Jerk in weight categories for female Olympic weightlifters.

Figure 7 shows the curved characteristics best suited for standard levels of the RS. Snatch, Performance time phase and performance total $\mathrm{T}$. for Clean \& Jerk lift in the different weight categories for female weightlifters.

Figure 8 shows the Curved characteristics growth rates and performance level for lifts snatch and clean \& jerk of Podobedova Svedana lifter winning first place and Abir Khalil Egyptian lifter in $75 \mathrm{~kg}$, ZHOU Lulu female lifter winning first place and Ramadan Nahla Egyptian lifter in $+75 \mathrm{~kg}$.
Figure 9 shows the Curved characteristics RS. snatch and performance time of Snatch for Podobedova Svedana female lifter winning first place and Abir Khalil Egyptian lifter in $75 \mathrm{~kg}$, Zhou Lulu lifter winning first place and Ramadan Nahla Egyptian lifter in $+75 \mathrm{~kg}$.

Figure 10 shows the Curved characteristics RS. Clean \&jerk and performance time of Clean \&jerk for Podobedova Svedana female lifter winning first place and Abir Khalil Egyptian lifter in $75 \mathrm{~kg}$, Zhou Lulu lifter winning first place and Ramadan Nahla Egyptian lifter in $+75 \mathrm{~kg}$. 


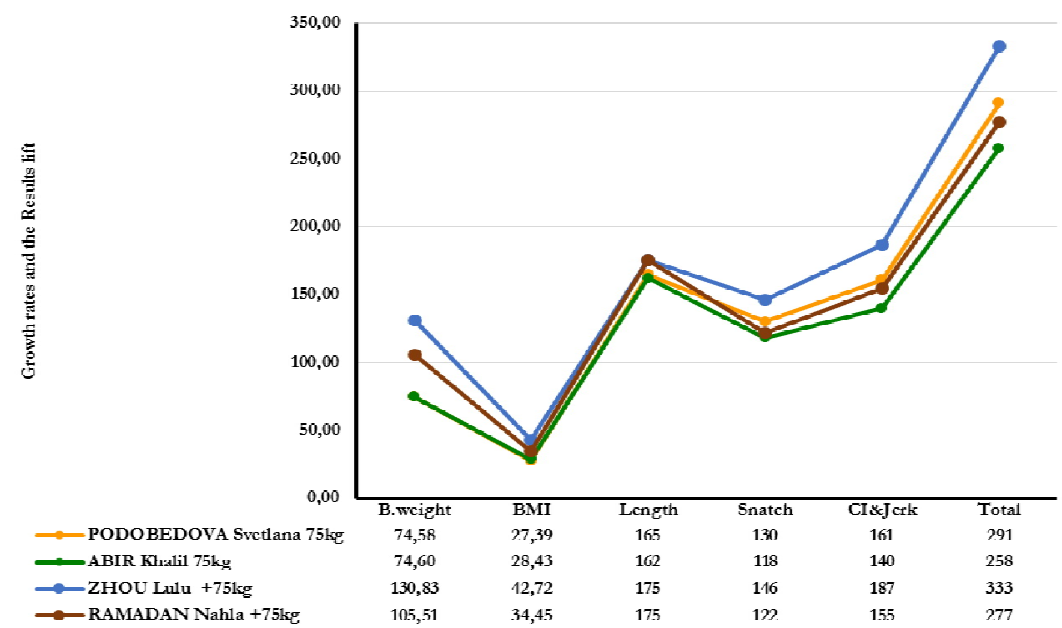

Figure 8. Curved characteristics Growth rates and performance level of female lifter winning first place, Egyptian lifter in $75 \mathrm{~kg}$, female lifter winning first place and Egyptian lifter in $+75 \mathrm{~kg}$.

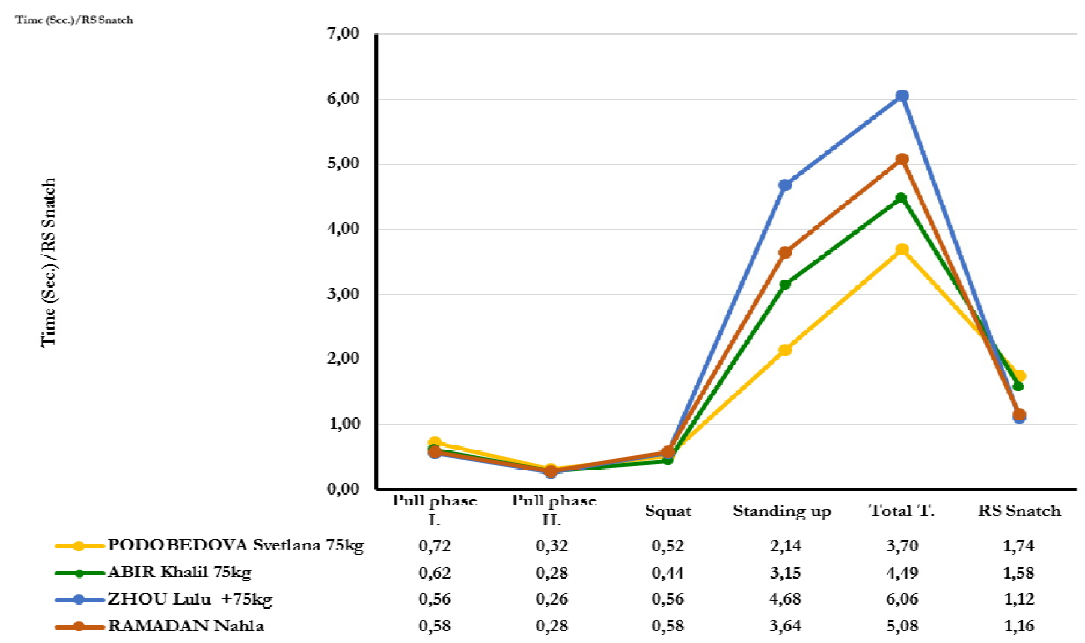

Figure 9. Curved characteristics Relative strength and performance time of Snatch for female lifter winning first place, Egyptian lifter in $75 \mathrm{~kg}$, female lifter winning first place and Egyptian lifter in $+75 \mathrm{~kg}$.

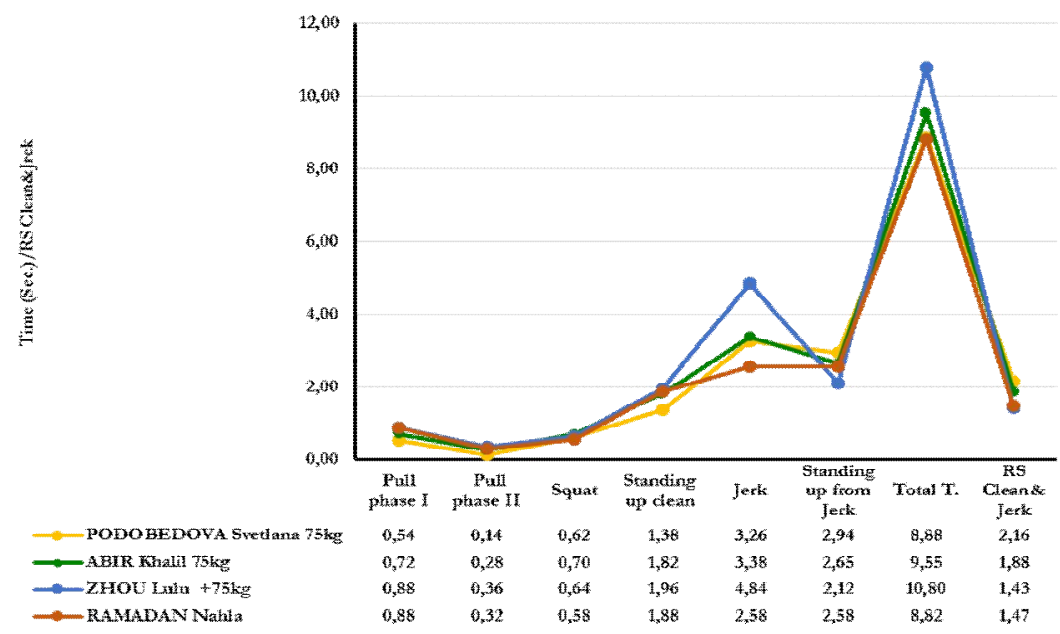

Figure 10. Curved characteristics for Relative strength and performance time of Clean \& Jerk for female lifter winning first place, Egyptian lifter in $75 \mathrm{~kg}$, female lifter winning first place and Egyptian lifter in $+75 \mathrm{~kg}$. 


\section{DISCUSSION}

Results showed a statistical analysis of the average growth rates and the results of snatch and clean \& jerk for female lifters table1 that the results of the lift depend on growth rates and strength for female lifters $75 \mathrm{~kg}$ category average age of $24.92 \pm 3.11$, and length $164.58 \pm 3.01$. Achieved results total lifts average $236.75 \pm 19.01$ while female lifters has achieved $63 \mathrm{~kg}$ category average age $27.44 \pm 2.96$ the highest average age of championship, average length $162.00 \pm 3.33$ and Total results $216.67 \pm 24.44 \mathrm{~kg}$. That rapprochement in level of performance between female lifters $69 \mathrm{~kg}$ and lifters $75 \mathrm{~kg}$ category, as it made lifters $69 \mathrm{~kg}$ average snatch $105.08 \pm 8.69$ and Clean \& jerk $130.30 \pm 10.49 \mathrm{~kg}$. While has achieved lifters $75 \mathrm{~kg}$ category average snatch $105.92 \pm 16.58$ and Clean \& jerk $130.30 \pm 16.67$ with different growth rates and strength between female lifters $(11,27,30)$.

There is also the superiority of female lifters 58 $\mathrm{kg}$ on female lifters $63 \mathrm{~kg}$ category where the results achieved female lifters $58 \mathrm{~kg}$ snatch average $98.00 \pm 6.00$ and Clean\& Jerk 123.38 \pm 8.20 , while female lifters achieved $63 \mathrm{~kg}$ category average results snatch of $96.78 \pm 11.19 \mathrm{~kg}$ and Clean\& Jerk $119.89 \pm 13.26 \mathrm{~kg}$. The table 2, 3 Shown superiority female lifters $58 \mathrm{~kg}$ category in the relative strength of the muscle group involved in Kinetic performance of the snatch and clean\& jerk, which achieved RS. Snatch an average $1.70 \pm 0.11$ the elevation of RS. Clean \& jerk average 2.14 \pm 0.14 , while achieved female lifters $63 \mathrm{~kg}$ category average RS. Snatch of $1.57 \pm 0.15$. The Clean \& jerk average $1.94 \pm 0.18$ is explained, however, that results as female weightlifters depend on differing growth rates and rate increase relative strength indicates the development of strength to muscle group involved in Kinetic performance of snatch and clean \& jerk for female weightlifting $(13,27,30)$. The results also showed that of performance time of pull phase II is less than a performance time pull phase I in each of snatch and clean\& jerk for female lifters $(11,12)$. Where short duration pull phase II indicates that I have the power female lifters much bigger than it was in the pull phase I, That is where the power = work/ time $\mathrm{P}=\mathrm{W} / \mathrm{T}(15,21,23,24,25)$. Results indicate the greater the relative strength of female lifter, the lower performance time phases of the lifting $(16,20)$. The researcher attributed the low performance in a time the pull phase II for the pull phase I to that pull phase II begin of placing movement, while start pull phase I of stability. As that female lifter after double- phase bending the knees be in a better mechanic put, where resistance to shorten the arm less as possible addition to the involvement of different muscle groups, arms, legs and trunk at work synchronously which increases the net force (6). Attributed researcher low time of pull phase I and of pull phase II, which is an indicator to increase the strength and power female lifters to control weight for the time of each squat phase and stand up heavyweight to pull female lifter (33). The weight of the barbell with all of its strength even to overcome the weight, force of gravity to lift the barbell and so increase the speed barbell.

Also showed results of Table 2, 3 rate increase RS. Snatch, RS. Clean\& jerk, low phases performance time and total time lifting for female lifters $48,53,58 \mathrm{~kg}$ categories, to the rate of relative strength and performance time for female lifters 63, $69,75,+75 \mathrm{~kg}$ categories. Indicates to the development of strength in the group the muscles involved in Kinetic performance female lifters of have reported lightweights in female lifters of heavy weights category $(4,28)$. This means that the greater the body mass and Barbell lifts less relative strength and phase's performance time increases. This confirms the superiority female lifters $58 \mathrm{~kg}$ on lifters $75,+75 \mathrm{~kg}$ category in RS. Snatch, RS. Clean \& clean and performance total $\mathrm{T}$. of lifts, including the increase in relative strength rate refers to development of strength in the muscle group to participate in the Kinetic performance of the lifts snatch and clean\& jerk for female lifters $58 \mathrm{~kg}$ category for muscle group involved in Kinetic performance for female lifters $75,+75 \mathrm{~kg}$ category. Who lack the strength and muscle mass compared with lightweights, so attention must be paid to developing muscle strength have lifters categories of heavyweights in the training programs and work to increase muscle mass they have $(12,13,14,19,22,28)$.

Show Figures 5, 6, 7 Curved characteristics best suited to the average growth rates, relative strength, performance time and results lifts snatch and clean \& jerk for female weightlifters, and the degree to standard interview $100 \%$ (13), the best values that can up to it female weightlifters at the moment. Where showed curved characteristics for female weightlifters in various weights categories the convergence in phase time Pull I, Pull II and Squat to lifts snatch and clean \& jerk. while the back of a difference from the beginning of the phase stand up for snatch and phase standup from clean to the end of the performance progress and it depends on 
different body mass, the mass weight raised and female lifter strength $(3,7,8,19)$. As shown by a curved characteristics the convergence in the level of the relative strength of the muscles involved in Kinetic performance, as well as lifting of performance time total of the lift, which should be characterized by female weightlifters. This has not been achieved female lifters participate in the session Olympics London 2012. Appeared this difference in the level of strength to female lifters different growth rates. A researcher sees that the female lifters and trainers should develop the maximum muscle strength in their training programs (33), and the use of standard levels of curved characteristics best suited to female weightlifters when evaluate the level of performance and results female lifters. The use of it when the selection female lifters national teams to participate championships and the Olympic Games. As shown by a curved characteristics best suited to female lifters $63,69 \mathrm{~kg}$ category that there is a convergence in the levels of standard growth rates, the relative strength and performance time of female lifters (13). Best results, especially for the expected female lifters $63 \mathrm{~kg}$ category snatch, clean\& jerk and total results respectively are $103.33,159.67,290.00 \mathrm{~kg}$, while the best results expected to female lifters $69 \mathrm{~kg}$ category are 131.14, 161.69, $292.33 \mathrm{~kg}$. This is due to a convergence in the plane female lifters convergence in growth rates and the extent of the weight category between female lifters a $6 \mathrm{~kg}$ (28).

Showed Percentile Scores Appendix 1 to the curved characteristics best suited anticipated to female lifters of $48,53,58 \mathrm{~kg}$ weight categories higher than range between $0.05-0.47 \mathrm{~kg}$. which is less than $0.50 \mathrm{~kg}$ of maximum weight category has attributed this increase to the percentage water or fat or waste products in the body female lifter, and which can disposed of which through different ways to lose weight with the aim of achieving best result of anticipated achievement $(22,31)$. According to the results of Percentile scores of $63 \mathrm{~kg}$ weight category notes that there are three levels of by weight significantly increase the maximum for the category and exceeding $0.50 \mathrm{~kg}$ weight is limited to between $63.88-65.38 \mathrm{~kg}$. Which calls researcher to change the scope of the recommendation that weighted category to become a maximum $66 \mathrm{~kg}$ category in order to achieve a better level of achievement expected of the weight category. Moreover, observing the results Percentile scores for female lifters of $69,75 \mathrm{~kg}$ weight category there are $69 \mathrm{~kg}$ more than one level for the maximum category amounted to $69.31 \mathrm{~kg}$. It also increased by three levels of by weight to female lifters $75 \mathrm{~kg}$ category has been narrowed down between $75.52-76.42 \mathrm{~kg}$ and researcher recommends in light of these findings to modify the maximum of $69 \mathrm{~kg}$ weight category to $71 \mathrm{~kg}$. as well as modify the maximum of $75 \mathrm{~kg}$ weight category to $77 \mathrm{~kg}$ in order to achieve the best results expected and the consequent lifting Minimum category next $+75 \mathrm{~kg}$ weighted to $+77 \mathrm{~kg}$. Therefore, researcher finds that the results of current study may contribute to bring attention of the International Federation of Weightlifting to amend the weight categories to female weightlifters beginning of $63 \mathrm{~kg}$ weight for the following class of 2-3 kg. (29), until the distinction between weight categories different results of female lifters, which can check numbers Olympics records new for female weightlifting competitions.

In addition, showed results curved characteristics to Egyptian female lifters team of 75, +75 $\mathrm{kg}$ categories in Figures 8, 9, 10 and Appendix 1 . Percentile scores Weaknesses in the Egyptian female lifters level of performance for lifts snatch and clean\& jerk through the clear quantity differences between the Egyptian female lifters compared sinusoidal characteristics model female lifters world's best and best suited curved characteristics. By comparing the values of the curved characteristics for Egyptian female lifters, team in Appendix 1. Percentile scores it is clear that performance level of the female lifters located between $55-65 \%$. Thus, clear difference in the level of achievement for records Egyptian female lifters team and a better world and curved characteristics female lifters most suitable this explains the Egyptian female lifters get the fifth place in the weightlifting competitions of the Olympic session to London 2012. Must therefore on the coaches and lifters concern for the development strengths of training programs for the Egyptian female lifters team $(6,33)$, and the use of curved characteristics best suited in the selection and female lifters evaluation.

The results showed the final curved characteristics best suited for growth rates, relative strength, results, and performance time phases for Snatch and Clean\& jerk lifts of female Olympic weightlifter, and determine the standard to assess the performance of Snatch and Clean \& Jerk in weightlifting. These results must be taken into account by the coaches and female lifter to use the standard guide them through planning, preparing 
weightlifting training programs and to evaluate the performance of snatch and Clean \& Jerk lifts for female lifters. Modified the weight categories for female weightlifters beginning of $63 \mathrm{~kg}$ weight for the following class of $2-3 \mathrm{~kg}$ until the distinction between the different weight categories results in female lifters, which can achieve for new Olympic Records in female weightlifting competitions.

\section{REFERENCES}

1. Ajan T. Olympic Weightlifting, Budapest, 2006.

2. Ajan, T, Carrard MF, Coffa S, Nagy R, Kayser B, Chinen R, Bulgaridhes J, Lassen M, Ádámfi A, Németh-Móra A. IWF Handbook Technical and competition rules \& regulations 2013-2016. IWF, 2013; Budapest.

3. Aydos L, Uzun A, Özel R, Esen E. Investigation of the relationship between physical characteristics and relative strength in weightlifters. Selçuk university journal of physical education and sport science, 2012; 14 (1): 31-36.

4. Bai X, Wang H, Zhang XA, Ji W, Wang C. Three-dimension kinematics simulation and biomechanics analysis of snatch technique. Computer Science in Sports, 2008; (1): 291296.

5. Barrow HM, Gee R.M. A Practical Approach to Measurement in Physical Education. Lea \& Febiger, second edition, 1976, USA, pp: 80.

6. Čupriks L. Ciematnieks U, Knipše G, Vidze A, Saulīte S, Lesčinskis $M$. Muscle strength characteristics of latvian weightlifters in single joint movements. Journal of Sport Science, 2011; 2(2): 1-11.

7. Ebada KH. Growth equation as a mark to the Prediction of Olympic Players results of Weightlifting Sport, in the first scientific conference "sport University in Arab countries from 6-7 Feb 2006: Physical Education of sport - Mansoura University, 2006.

8. Ebada KH. Relative strength, Body mass and height as Predictors of Olympic Weightlifting Players Performance. Selçuk Unıversıty Journal of Physıcal Educatıon and Sport Science, 2011; 13(2): 166-171. 5.

9. Ebada KH. The impact of ballistic training on explosive power development and some biomechanics parameters for lifting the snatch youth weightlifters, international sport science students conference 2013 (ISSSC 2013) from 28 \& 29 November 2013, Sports Centre, University of Malaya.

10. Ebada, KH, Abdel Hadi I. The effect of development of muscular balance on some dynamic parameters and level of achievement for clean and jerk skill for weightlifters. Science, movement and health, 2013; 13(2) Supplement: 172-182.

11. Ford LE, Alvin JD, Kevin HO, Wenyuan C. Gender- and height-related limits of muscle strength in world weightlifting champions. J Appl Physiol, 2000; 89: 1061-1064.

12. Garhammer J. A comparison of maximal power outputs between elite male and female weightlifters in competition. Int J Sport Biomech, 1991; 7: 3-11.

13. Haff GG, Carlock MJ, Hartman JL, Kil- gore N, Kawamori JR, Jackson RT, Morris WA, Sands M. Stone. Force-time curve characteristics of dynamic and isometric muscle actions of elite women Olympic weightlifters. J. Strength Cond. Res, 2005; 19(4):741-748.

14. Haleczko A. Indices of the Relative Strength Fitness of The Disabled Weightlifters. Kinesiology, 2001; 11(22): 21-25.

15. Harbili E. A gender-based kinematic and kinetic analysis of the snatch lift in elite weight- lifters in $69-\mathrm{kg}$ category. Journal of Sports Science and Medicine, 2012;11: 162-169.

16. Hasan A. Kinematic analysis of the snatch lift with elite female weightlifters during the 2010 world weightlifting championship, Journal of Strength and Conditioning Research, 2012.; 26(4):897-905.

17. http://www.bbc.co.uk/sport/olympics/2012/sports/weightlifti ng/events, 30.1.2014.12.30 Am.

18. IFW. Official results book Weightlifting London 2012. http://www.iwf.net/wpcontent/uploads/downloads/2012/08/R esults-Book.pdf, 2012; Budapest.

19. Kanyevsky VV. The Dependence between the Weightlifter's Absolute and Relative Strength on Weight Class. Translated by Andrew Charniga, Jr. Sportivny, Press. Russian. http://www.dynamiceleiko.com/sportivny/library/news/nv00 6.html, 2003.

20. Kipp K, Redden J, Sabick M, Harris C. Kinematic and Kinetic Synergies of the Lower Extremities During the Pull in Olympic Weightlifting, Journal of Applied Biomechanics, 2012; 28: 271-278.

21. Knudson DV. Fundamentals of biomechanics. (2th ed.). Springer, USA., 2007; 115-157.

22. Markovi G, Sekuli D. Modeling the Influence of Body Size on Weightlifting and Powerlifting Performance. Coll. Antropol, 2006; 30(3): 607-613.

23. McGinnis P. Biomechanics of sport and exercise. (3rd ed.). Human Kinetics. Canada, 2013; 62-112.

24. Nordin M, Frankel VH. Basic biomechanics of the musculoskeletal system. Wolters Kluwer Health. (3rd ed.), Maryland: USA., 2001; 6.

25. Robertson DG. Research methods in biomechanics. Human Kinetics, USA., 2004; 29-135

26. Sato K., Paul FP, Sands W. Barbell acceleration analysis on various intensities of weightlifting. ISBS-Conference Proceedings Archive, 2009; 1(1)

27. Stone MH, Sands WA, Pierce KC, Carlock J, Cardinale M, Newton R. Relationship of Maximum Strength to Weightlifting Performance. Medicine \& Science in Sports \& Exercise, 2005; 37(6):1037-1043.

28. Szabo AS, Nemeth-Mora A, Adamfi A, Tolnay P. Comparative analysis of balanced state of weightlifting results of male and female competitors at the london 2012 olympic games. Sport SPA, 2013;10(1): 63-66.

29. Szabo, AS. Some questions of biomechanical character in weightlifting. Sport Scientific \& Practical Aspects, 2012; 9(1).

30. The DJ, Lori PS. Age, Body Mass, and Gender as Predictors of Masters Olympic Weightlifting Performance. Med. Sci. Sports Exerc, 2003; 35(7):1216-1224.

31. Turocy PS, DePalma EF, Horswill CA, Laquale KM, Thomas J. Martin TJ, Perry AC, Somova MS, Utter AC. National Athletic Trainers' Association Position Statement: Safe 
Weight Loss and Maintenance Practices in Sport and Exercise, Journal of Athletic Training, 2011; 46(3):322-336.

32. Urso A. Weightlifting: comparing three editions of the olympic games, strength \& conditioning, 2013; 2(4)

33. Zebas C., Carlson K., Chrstensen B, Daniel G, Hayes M. Power output in women weightlifters during the pull phase of the snatch. ISBS-Conference Proceedings Archive, 2000; $1(1)$. 
Ebada 2014

\begin{tabular}{|c|c|c|c|c|c|c|c|c|c|c|c|c|c|c|c|c|c|c|c|c|c|}
\hline \multirow[b]{2}{*}{ Weight categories } & \multirow[b]{2}{*}{$\begin{array}{c}\text { Present } \\
\%\end{array}$} & \multicolumn{3}{|c|}{ Growth rates } & \multicolumn{3}{|c|}{ Results(kg) } & \multicolumn{5}{|c|}{ Performance time snatch (Sec.) } & \multirow{2}{*}{$\begin{array}{c}\text { RS } \\
\text { Snatch }\end{array}$} & \multicolumn{7}{|c|}{ Performance Clean \& jerk (Sec.) } & \multirow{2}{*}{$\begin{array}{c}\text { RS } \\
\text { Clean\& } \\
\text { Jerk } \\
\end{array}$} \\
\hline & & $\begin{array}{c}\text { Body } \\
\text { Weight } \\
\end{array}$ & BMI & Length & Snatch & $\begin{array}{l}\text { CI \& } \\
\text { Jerk }\end{array}$ & Total & $\begin{array}{c}\text { Pull } \\
\text { phase I. }\end{array}$ & $\begin{array}{l}\text { Pull phase } \\
\text { II. }\end{array}$ & Squat & $\begin{array}{c}\text { Standing } \\
\text { up }\end{array}$ & $\begin{array}{c}\text { Total } \\
\mathrm{T} \text {. } \\
\end{array}$ & & $\begin{array}{l}\text { Pull } \\
\text { phase I }\end{array}$ & $\begin{array}{c}\text { Pull } \\
\text { phase II }\end{array}$ & Squat & $\begin{array}{l}\text { Standing } \\
\text { up clean }\end{array}$ & Jerk & $\begin{array}{l}\text { Standing up } \\
\text { from Jerk }\end{array}$ & $\begin{array}{c}\text { Total } \\
\text { T. } \\
\end{array}$ & \\
\hline & 100 & 48.23 & 24.20 & 160.29 & 98.33 & 126.26 & 223.20 & 0.24 & 0.21 & 0.40 & 2.43 & 3.49 & 2.08 & 0.34 & 0.21 & 0.41 & 2.44 & 1.21 & 2.03 & 8.21 & \\
\hline & 90 & 48.10 & 23.62 & 158.18 & 94.16 & 121.06 & 214.10 & 0.28 & 0.22 & 0.43 & 2.45 & 3.54 & 1.99 & 0.37 & 0.23 & 0.43 & 2.66 & 1.41 & 2.08 & 8.44 & 2.56 \\
\hline & 80 & 47.97 & 23.03 & 156.06 & 89.98 & 115.86 & 205.01 & 0.32 & 0.24 & 0.45 & 2.47 & 3.60 & 1.90 & 0.41 & 0.25 & 0.45 & 2.87 & 1.60 & 2.13 & 8.67 & 2.45 \\
\hline & 70 & 47.84 & 22.45 & 153.95 & 85.80 & 110.67 & 195.92 & 0.36 & 0.25 & 0.48 & 2.48 & 3.65 & 1.81 & 0.44 & 0.27 & 0.47 & 3.09 & 1.80 & 2.17 & 8.90 & 2.33 \\
\hline & 60 & 47.71 & 21.87 & 151.84 & 81.63 & 105.47 & 186.82 & 0.40 & 0.26 & 0.50 & 2.50 & 3.70 & 1.72 & 0.47 & 0.29 & 0.49 & 3.30 & 2.00 & 2.22 & 9.13 & 2.22 \\
\hline \multirow[t]{11}{*}{$48 \mathrm{~kg}$} & 50 & 47.59 & 21.29 & 149.73 & 77.45 & $\begin{array}{l}100.27 \\
\end{array}$ & 177.73 & 0.45 & 0.27 & 0.53 & 2.51 & 3.76 & 1.63 & 0.51 & 0.31 & 0.51 & 3.52 & 2.20 & 2.26 & 9.36 & 2.11 \\
\hline & 40 & 47.46 & 20.71 & \begin{tabular}{|l|l|}
147.61 \\
\end{tabular} & 73.28 & 95.08 & 168.63 & 0.49 & 0.28 & 0.55 & 2.53 & 3.81 & 1.54 & 0.54 & 0.33 & 0.53 & 3.74 & 2.39 & 2.31 & 9.60 & 2.00 \\
\hline & 30 & 47.33 & 20.13 & 145.50 & 69.10 & 89.88 & 159.54 & 0.53 & 0.29 & 0.58 & 2.55 & 3.86 & 1.45 & 0.57 & 0.35 & 0.55 & 3.95 & 2.59 & 2.36 & $\begin{array}{l}9.83 \\
\end{array}$ & 1.88 \\
\hline & 20 & 47.20 & 19.55 & 143.39 & 64.93 & 84.68 & 150.44 & 0.57 & 0.30 & 0.60 & 2.56 & 3.91 & 1.36 & 0.60 & 0.37 & 0.57 & 4.17 & 2.79 & 2.40 & 10.06 & 1.77 \\
\hline & 10 & $\begin{array}{l}47.07 \\
\end{array}$ & 18.97 & 141.28 & 60.75 & 79.49 & 141.35 & 0.61 & 0.31 & 0.63 & 2.58 & 3.97 & 1.27 & 0.64 & 0.40 & 0.59 & 4.38 & 2.98 & 2.45 & 10.29 & 1.66 \\
\hline & 0 & 46.95 & 18.38 & $\begin{array}{l}139.17 \\
\end{array}$ & 56.58 & 74.29 & 132.26 & 0.65 & 0.32 & 0.65 & 2.59 & 4.02 & 1.18 & 0.67 & 0.42 & 0.61 & 4.60 & 3.18 & 2.49 & 10.52 & 1.54 \\
\hline & 100 & 53.05 & 25.55 & 183.62 & 106.48 & \begin{tabular}{|l|l|}
133.04 \\
\end{tabular} & 233.04 & 0.36 & 0.25 & $\begin{array}{l}0.44 \\
\end{array}$ & 2.29 & 3.47 & 1.99 & 0.26 & 0.23 & 0.37 & 1.13 & 2.84 & 1.56 & 8.01 & 2.53 \\
\hline & 90 & 52.95 & 24.76 & 178.24 & 102.30 & 128.27 & 225.47 & 0.41 & 0.26 & 0.47 & 2.34 & 3.59 & 1.92 & 0.30 & 0.25 & 0.40 & 1.26 & 2.94 & 1.73 & 8.18 & 2.44 \\
\hline & 80 & 52.85 & 23.96 & 172.87 & 98.12 & 123.50 & 217.90 & 0.45 & 0.27 & 0.51 & 2.39 & 3.70 & 1.85 & 0.35 & 0.27 & 0.42 & 1.39 & 3.03 & 1.91 & 8.34 & 2.35 \\
\hline & 70 & 52.75 & 23.17 & 167.49 & 93.94 & 118.74 & 210.34 & 0.49 & 0.29 & 0.54 & 2.45 & 3.82 & 1.78 & 0.39 & 0.29 & 0.45 & 1.52 & 3.13 & 2.08 & 8.51 & 2.26 \\
\hline & 60 & 52.65 & 22.38 & 162.11 & 89.76 & $\begin{array}{l}113.97 \\
\end{array}$ & 202.77 & 0.54 & 0.30 & 0.58 & 2.50 & 3.94 & 1.71 & 0.44 & 0.30 & 0.48 & 1.66 & 3.22 & 2.26 & 8.68 & $\begin{array}{l}2.17 \\
\end{array}$ \\
\hline \multirow[t]{11}{*}{$53 \mathrm{~kg}$} & 50 & 52.55 & 21.59 & 156.73 & 86.00 & $\begin{array}{l}109.20 \\
\end{array}$ & 195.20 & 0.58 & 0.31 & $\begin{array}{l}0.61 \\
\end{array}$ & 2.55 & 4.05 & 1.64 & 0.48 & 0.32 & 0.51 & 1.79 & $\begin{array}{l}3.32 \\
\end{array}$ & 2.43 & $\begin{array}{l}8.85 \\
\end{array}$ & 2.08 \\
\hline & 40 & 52.46 & 20.80 & $\begin{array}{l}153.51 \\
\end{array}$ & 82.24 & 104.43 & 187.63 & 0.62 & 0.33 & 0.64 & 2.61 & 4.17 & 1.57 & 0.53 & 0.35 & 0.54 & 1.92 & 3.41 & 2.61 & 9.02 & 1.99 \\
\hline & 30 & 52.36 & 20.01 & 150.28 & 78.48 & 99.66 & 180.06 & 0.67 & 0.35 & 0.68 & 2.66 & 4.29 & 1.50 & 0.57 & 0.38 & 0.56 & 2.06 & 3.51 & 2.78 & 9.19 & 1.90 \\
\hline & 20 & 52.26 & 19.21 & 147.05 & 74.72 & 94.90 & 172.50 & 0.71 & 0.37 & 0.71 & 2.71 & 4.40 & 1.43 & 0.62 & 0.41 & 0.59 & 2.19 & 3.60 & 2.96 & 9.36 & 1.81 \\
\hline & 10 & 52.16 & 18.42 & 144.83 & 70.96 & $\begin{array}{l}90.13 \\
\end{array}$ & 164.93 & 0.75 & 0.39 & 0.75 & 2.76 & 4.52 & 1.36 & 0.67 & 0.44 & 0.62 & 2.32 & 3.69 & 3.13 & $\begin{array}{c}9.53 \\
\end{array}$ & 1.72 \\
\hline & 0 & $\begin{array}{l}52.06 \\
\end{array}$ & 177.63 & \begin{tabular}{l|l|}
140.60 \\
\end{tabular} & $\begin{array}{l}67.20 \\
\end{array}$ & 85.36 & 157.36 & 0.80 & 0.41 & \begin{tabular}{|l|l}
0.78 \\
\end{tabular} & 2.82 & \begin{tabular}{|l|l}
4.64 \\
\end{tabular} & 1.28 & 0.71 & 0.47 & 0.65 & 2.46 & \begin{tabular}{|l|}
3.79 \\
\end{tabular} & 3.31 & $\begin{array}{l}9.70 \\
\end{array}$ & 1.63 \\
\hline & 100 & 58.47 & 27.05 & $\begin{array}{l}169.38 \\
\end{array}$ & 116.00 & 147.98 & 262.72 & 0.54 & 0.30 & $\begin{array}{l}0.54 \\
\end{array}$ & 2.41 & 3.82 & 2.02 & 0.43 & 0.25 & 0.54 & 1.40 & 1.63 & 1.96 & 6.87 & 2.57 \\
\hline & 90 & 58.30 & 26.33 & 166.90 & 112.40 & 143.06 & 254.45 & 0.55 & 0.30 & 0.56 & 2.42 & 3.86 & 1.95 & 0.46 & 0.27 & 0.55 & 1.47 & 1.80 & 2.01 & 7.08 & 2.49 \\
\hline & 80 & 58.14 & 25.61 & 164.43 & 108.80 & 138.14 & 246.18 & 0.55 & 0.31 & $\begin{array}{l}0.58 \\
\end{array}$ & 2.43 & 3.90 & 1.89 & 0.50 & 0.28 & $\begin{array}{l}0.56 \\
\end{array}$ & 1.53 & 1.96 & 2.06 & 7.30 & 2.40 \\
\hline & 70 & 57.97 & 24.89 & $\begin{array}{l}161.95 \\
\end{array}$ & $\begin{array}{l}105.20 \\
\end{array}$ & 133.22 & 237.91 & 0.56 & 0.32 & $\begin{array}{l}0.60 \\
\end{array}$ & 2.44 & 3.93 & 1.83 & 0.53 & 0.30 & 0.57 & 1.60 & 2.13 & 2.11 & $\begin{array}{l}7.52 \\
\end{array}$ & 2.31 \\
\hline & 60 & \begin{tabular}{|l}
57.81 \\
\end{tabular} & 24.17 & \begin{tabular}{|l|l|}
159.48 \\
\end{tabular} & $\begin{array}{l}101.60 \\
\end{array}$ & \begin{tabular}{l|l|}
128.30 \\
\end{tabular} & 229.64 & 0.57 & 0.33 & \begin{tabular}{|l|}
0.63 \\
\end{tabular} & 2.45 & $\begin{array}{l}3.97 \\
\end{array}$ & 1.76 & 0.57 & 0.32 & 0.59 & 1.66 & $\begin{array}{l}2.30 \\
\end{array}$ & 2.16 & $\begin{array}{l}7.74 \\
\end{array}$ & 2.23 \\
\hline \multirow[t]{11}{*}{$58 \mathrm{~kg}$} & 50 & 57.65 & 23.45 & 157.00 & 98.00 & 123.38 & 221.38 & 0.57 & 0.33 & 0.65 & 2.46 & 4.01 & 1.70 & 0.61 & 0.34 & 0.60 & 1.73 & 2.47 & 2.21 & 7.96 & 2.14 \\
\hline & 40 & 57.48 & 22.73 & 154.53 & 94.40 & 118.45 & 213.11 & 0.58 & 0.34 & 0.67 & 2.46 & 4.04 & 1.64 & 0.64 & 0.35 & 0.61 & 1.80 & 2.64 & 2.27 & 8.17 & 2.05 \\
\hline & 30 & 57.32 & 22.01 & 152.05 & $\begin{array}{l}90.80 \\
\end{array}$ & 113.53 & 204.84 & 0.58 & 0.35 & $\begin{array}{l}0.69 \\
\end{array}$ & 2.47 & 4.08 & 1.57 & 0.68 & 0.37 & 0.62 & 1.86 & 2.81 & 2.32 & 8.39 & 1.97 \\
\hline & 20 & 57.15 & 21.29 & 149.58 & $\begin{array}{l}87.20 \\
\end{array}$ & \begin{tabular}{|l|l|}
108.61 \\
\end{tabular} & $\begin{array}{c}196.57 \\
\end{array}$ & 0.59 & 0.36 & $\begin{array}{l}0.71 \\
\end{array}$ & 2.48 & 4.12 & 1.51 & 0.71 & 0.39 & 0.64 & 1.93 & 2.98 & 2.37 & $\begin{array}{l}8.61 \\
\end{array}$ & $\begin{array}{l}1.88 \\
\end{array}$ \\
\hline & 10 & $\begin{array}{l}56.99 \\
\end{array}$ & 20.57 & \begin{tabular}{|l|l|l|l|} 
\\
\end{tabular} & $\begin{array}{l}83.60 \\
\end{array}$ & \begin{tabular}{ll|}
103.69 \\
\end{tabular} & 188.30 & 0.59 & 0.36 & $\begin{array}{ll}0.73 \\
\end{array}$ & 2.49 & $\begin{array}{l}4.16 \\
\end{array}$ & 1.45 & 0.75 & 0.41 & 0.65 & 1.99 & 3.15 & 2.42 & $\begin{array}{l}8.83 \\
\end{array}$ & $\begin{array}{l}1.79 \\
\end{array}$ \\
\hline & 0 & 56.82 & 19.85 & 144.63 & 80.00 & $\begin{array}{l}98.77 \\
\end{array}$ & 180.03 & 0.60 & 0.37 & $\begin{array}{l}0.75 \\
\end{array}$ & 2.50 & 4.19 & 1.38 & 0.78 & 0.43 & 0.66 & 2.06 & 3.32 & 2.47 & 9.05 & 1.71 \\
\hline & 100 & $\begin{array}{l}65.38 \\
\end{array}$ & 25.73 & 172.00 & 130.33 & 159.67 & 290.00 & 0.49 & 0.25 & 0.66 & 1.60 & 3.12 & 2.02 & 0.51 & 0.29 & 0.33 & 1.56 & 1.85 & 2.95 & 8.27 & 2.48 \\
\hline & 90 & $\begin{array}{l}64.63 \\
\end{array}$ & 25.28 & 170.00 & 123.62 & 151.71 & 275.33 & 0.50 & 0.26 & 0.66 & 1.92 & 3.44 & 1.93 & 0.55 & 0.29 & 0.37 & 1.71 & 2.08 & 3.00 & 8.63 & 2.37 \\
\hline & 80 & 63.88 & 24.84 & 168.00 & 116.91 & 143.76 & 260.67 & 0.51 & 0.27 & $\begin{array}{l}0.67 \\
\end{array}$ & 2.24 & 3.76 & 1.84 & 0.59 & 0.30 & 0.41 & 1.87 & 2.31 & 3.04 & 8.99 & 2.26 \\
\hline & 70 & 63.12 & 24.39 & 166.00 & 110.20 & 135.80 & 246.00 & 0.52 & 0.28 & \begin{tabular}{|l|l|}
0.67 \\
\end{tabular} & 2.57 & 4.08 & 1.75 & 0.63 & 0.31 & 0.45 & 2.02 & 2.55 & 3.08 & 9.35 & 2.16 \\
\hline & 60 & 62.37 & 23.95 & 164.00 & 103.49 & 127.84 & 231.33 & 0.53 & 0.29 & 0.68 & 2.89 & 4.40 & 1.66 & 0.67 & 0.32 & 0.48 & 2.18 & 2.78 & 3.12 & 9.71 & 2.05 \\
\hline \multirow[t]{6}{*}{$63 \mathrm{~kg}$} & 50 & 61.62 & 23.50 & 162.00 & 96.78 & 119.89 & 216.67 & 0.54 & 0.30 & 0.68 & 3.21 & 4.73 & 1.57 & 0.71 & 0.33 & 0.52 & 2.33 & 3.01 & 3.17 & 10.07 & 1.94 \\
\hline & 40 & 60.87 & 23.06 & 160.00 & 90.07 & 111.93 & 202.00 & 0.55 & 0.31 & 0.68 & 3.53 & 5.05 & 1.48 & 0.76 & 0.33 & 0.56 & 2.48 & 3.24 & 3.21 & 10.43 & 1.83 \\
\hline & 30 & 60.11 & 22.61 & 158.00 & 83.36 & 103.98 & 187.33 & 0.56 & 0.32 & 0.69 & 3.86 & 5.37 & 1.38 & 0.80 & 0.34 & 0.59 & 2.64 & 3.47 & 3.25 & 10.78 & 1.73 \\
\hline & 20 & 59.36 & 22.17 & 156.00 & 76.64 & 96.02 & 172.67 & 0.56 & 0.32 & 0.69 & 4.18 & 5.69 & 1.29 & 0.84 & 0.35 & 0.63 & 2.79 & 3.71 & 3.29 & 11.14 & 1.62 \\
\hline & 10 & 58.61 & 21.72 & 154.00 & 69.93 & 88.07 & 158.00 & 0.57 & 0.33 & 0.70 & 4.50 & 6.01 & 1.20 & 0.88 & 0.36 & 0.67 & 2.95 & 3.94 & 3.34 & 11.50 & 1.51 \\
\hline & - & 57.86 & 21.28 & 152.00 & 63.22 & 80.11 & 143.33 & 0.58 & 0.34 & 0.70 & 4.82 & 6.33 & 1.11 & 0.92 & 0.37 & 0.71 & 3.10 & 4.17 & 3.38 & 11.86 & 41 \\
\hline
\end{tabular}

Turk J Sport Exe 2014; IG(I): III6-127

๑2 2014 Department of Physical Education and Sport, Selcuk University 


\begin{tabular}{|c|c|c|c|c|c|c|c|c|c|c|c|c|c|c|c|}
\hline \multicolumn{16}{|c|}{ Appendix 1 . Table continued } \\
\hline \multirow[t]{7}{*}{ Weight categories } & & \multicolumn{3}{|c|}{ Growth rates } & \multicolumn{3}{|c|}{ Results (kg) } & \multicolumn{5}{|c|}{ Performance time snatch (Sec.) } & \multirow{2}{*}{$\begin{array}{c}\text { RS } \\
\text { Snatch }\end{array}$} & \multirow[b]{2}{*}{$\begin{array}{c}\text { Pull } \\
\text { phase I }\end{array}$} & \multirow[b]{2}{*}{$\begin{array}{c}\text { Pull } \\
\text { phase II }\end{array}$} \\
\hline & present $\%$ & B.weight & BMI & Length & Snatch & CI\&Jerk & Total & $\begin{array}{c}\text { Pull } \\
\text { phase I. }\end{array}$ & $\begin{array}{l}\text { Pull phase } \\
\text { II. }\end{array}$ & Squat & $\begin{array}{c}\text { Standing } \\
\text { up }\end{array}$ & $\begin{array}{c}\text { Total } \\
\text { T. }\end{array}$ & & & \\
\hline & 100 & 69.31 & 28.77 & 169.60 & 131.14 & 161.69 & 292.33 & 0.59 & 0.26 & 0.60 & 2.50 & 4.13 & 1.92 & 0.40 & 0.32 \\
\hline & 90 & 69.13 & 28.27 & 168.01 & 125.92 & 155.40 & 280.92 & 0.61 & 0.27 & 0.65 & 2.69 & 4.36 & 1.84 & 0.47 & 0.34 \\
\hline & 80 & 68.96 & 27.76 & 166.41 & 120.71 & 149.10 & 269.52 & 0.64 & 0.28 & 0.69 & 2.88 & 4.60 & 1.76 & 0.55 & 0.36 \\
\hline & 70 & 68.78 & 27.25 & 164.81 & 115.50 & 142.81 & 258.11 & 0.66 & 0.29 & 0.74 & 3.07 & 4.83 & 1.69 & 0.62 & 0.38 \\
\hline & 60 & 68.61 & 26.74 & 163.21 & 110.29 & 136.52 & 246.71 & 0.69 & 0.30 & 0.79 & 3.26 & 5.06 & 1.61 & 0.69 & 0.40 \\
\hline \multirow[t]{11}{*}{$69 \mathrm{~kg}$} & 50 & 68.43 & 26.23 & 161.62 & 105.08 & 130.23 & 235.31 & 0.71 & 0.31 & 0.83 & 3.45 & 5.29 & 1.54 & 0.77 & 0.42 \\
\hline & 40 & 68.25 & 25.72 & 160.02 & 99.87 & 123.94 & 223.90 & 0.73 & 0.32 & 0.88 & 3.64 & 5.53 & 1.46 & 0.84 & 0.43 \\
\hline & 30 & 68.08 & 25.21 & 158.42 & 94.65 & 117.65 & 212.50 & 0.76 & 0.33 & 0.92 & 3.83 & 5.76 & 1.38 & 0.92 & 0.45 \\
\hline & 20 & 67.90 & 24.70 & 156.82 & 89.44 & 111.36 & 201.10 & 0.78 & 0.34 & 0.97 & 4.02 & 5.99 & 1.31 & 0.99 & 0.47 \\
\hline & 10 & 67.73 & 24.19 & 155.22 & 84.23 & 105.07 & 189.69 & 0.80 & 0.35 & 1.02 & 4.21 & 6.23 & 1.23 & 1.07 & 0.49 \\
\hline & 0 & 67.55 & 23.68 & 153.63 & 79.02 & 98.78 & 178.29 & 0.83 & 0.36 & 1.06 & 4.40 & 6.46 & 1.15 & 1.14 & 0.51 \\
\hline & 100 & 76.42 & 30.28 & 173.63 & 155.67 & 180.83 & 336.50 & 0.48 & 0.24 & 0.40 & 2.11 & 3.54 & 2.09 & 0.40 & 0.18 \\
\hline & 90 & 75.97 & 29.71 & 171.82 & 145.72 & 170.83 & 316.55 & 0.51 & 0.25 & 0.42 & 2.27 & 3.70 & 1.96 & 0.45 & 0.19 \\
\hline & 80 & 75.52 & 29.15 & 170.01 & 135.77 & 160.83 & 296.60 & 0.54 & 0.27 & 0.43 & 2.44 & 3.87 & 1.83 & 0.49 & 0.21 \\
\hline & 70 & 75.08 & 28.58 & 168.20 & 125.82 & 150.83 & 276.65 & 0.58 & 0.28 & 0.45 & 2.61 & 4.04 & 1.69 & 0.54 & 0.22 \\
\hline & 60 & 74.63 & 28.01 & 166.39 & 115.87 & 140.83 & 256.70 & 0.61 & 0.29 & 0.46 & 2.78 & 4.21 & 1.56 & 0.59 & 0.24 \\
\hline \multirow[t]{11}{*}{$75 \mathrm{~kg}$} & 50 & 74.18 & 27.44 & 164.58 & 105.92 & 130.83 & 236.75 & 0.64 & 0.31 & 0.48 & 2.95 & 4.37 & 1.43 & 0.64 & 0.26 \\
\hline & 40 & 73.73 & 26.87 & 162.78 & 95.97 & 120.83 & 216.80 & 0.67 & 0.32 & 0.50 & 3.12 & 4.54 & 1.30 & 0.68 & 0.27 \\
\hline & 30 & 73.28 & 26.30 & 160.97 & 86.02 & 110.83 & 196.85 & 0.70 & 0.33 & 0.51 & 3.28 & 4.71 & 1.16 & 0.73 & 0.29 \\
\hline & 20 & 72.84 & 25.74 & 159.16 & 76.07 & 100.83 & 176.90 & 0.74 & 0.34 & 0.53 & 3.45 & 4.87 & 1.03 & 0.78 & 0.30 \\
\hline & 10 & 72.39 & 25.17 & 157.35 & 66.12 & 90.83 & 156.95 & 0.77 & 0.36 & 0.54 & 3.62 & 5.04 & 0.90 & 0.83 & 0.32 \\
\hline & 0 & 71.94 & 24.60 & 155.54 & 56.17 & 80.83 & 137.00 & 0.80 & 0.37 & 0.56 & 3.79 & 5.21 & 0.76 & 0.87 & 0.34 \\
\hline & 100 & 161.21 & 51.82 & 185.50 & 160.00 & 205.00 & 363.50 & 0.49 & 0.22 & 0.52 & 2.77 & 4.21 & 1.57 & 0.45 & 0.29 \\
\hline & 90 & 151.15 & 49.02 & 182.60 & 151.60 & 193.65 & 344.05 & 0.51 & 0.23 & 0.52 & 2.97 & 4.40 & 1.48 & 0.51 & 0.30 \\
\hline & 80 & 141.10 & 46.22 & 179.70 & 143.20 & 182.30 & 324.60 & 0.52 & 0.24 & 0.53 & 3.16 & 4.60 & 1.38 & 0.58 & 0.31 \\
\hline & 70 & 131.04 & 43.43 & 176.80 & 134.80 & 170.95 & 305.15 & 0.54 & 0.26 & 0.54 & 3.36 & 4.79 & 1.28 & 0.65 & 0.33 \\
\hline & 60 & 120.98 & 40.63 & 173.90 & 126.40 & 159.60 & 285.70 & 0.55 & 0.27 & 0.55 & 3.56 & 4.98 & 1.19 & 0.72 & 0.34 \\
\hline \multirow[t]{6}{*}{$+75 \mathrm{~kg}$} & 50 & 110.92 & 37.83 & 171.00 & 118.00 & 148.25 & 266.25 & 0.57 & 0.29 & 0.56 & 3.76 & 5.18 & 1.09 & 0.79 & 0.35 \\
\hline & 40 & 100.86 & 35.04 & 168.10 & 109.60 & 136.90 & 246.80 & 0.59 & 0.30 & 0.57 & 3.96 & 5.37 & 0.99 & 0.85 & 0.36 \\
\hline & 30 & 90.80 & 32.24 & 165.20 & 101.20 & 125.55 & 227.35 & 0.60 & 0.31 & 0.58 & 4.16 & 5.56 & 0.89 & 0.92 & 0.37 \\
\hline & 20 & 80.74 & 29.44 & 162.30 & 92.80 & 114.20 & 207.90 & 0.62 & 0.33 & 0.59 & 4.36 & 5.76 & 0.80 & 0.99 & 0.39 \\
\hline & 10 & 70.68 & 26.65 & 159.40 & 84.40 & 102.85 & 188.45 & 0.63 & 0.34 & 0.60 & 4.56 & 5.95 & 0.70 & 1.06 & 0.40 \\
\hline & 0 & 60.62 & 23.85 & 156.50 & 76.00 & 91.50 & 169.00 & 0.65 & 0.35 & 0.61 & 4.75 & 6.14 & 0.60 & 1.13 & 0.41 \\
\hline
\end{tabular}

Turk ل Sport Exe 2014; I6() : III6-127

匹 2014 Department of Physical Education and Sport, Selcuk University 